\title{
Accretionary lapilli in Pliocene volcaniclastics from Grad, northeastern Slovenia
}

\author{
Akrecijski lapili v pliocenskih vulkanoklastitih Grada, severovzhodna Slovenija
}

Polona KRALJ

Geološki zavod Slovenije, Dimičeva 14, 1000 Ljubljana

\begin{abstract}
Key words: accretionary lapilli, armoured lapilli, volcaniclastics, hydrovolcanic eruptions, resedimented volcaniclastics, Slovenia

Ključne besede: akrecijski lapili, oblepljeni lapili, vulkanoklastiti, hidrovulkanske eksplozije, presedimentirani vulkanoklastiti, Slovenija
\end{abstract}

\begin{abstract}
The Grad area, north-eastern Slovenia is characterised by Upper Pliocene volcanic activity, which produced minor lava flows and scoria deposits. In the late-stage of volcanic activity, hydrovolcanism predominated and it produced pyroclastic surge deposits rich in accretionary lapilli. This alkali basaltic (basanitic) volcanism occurred on the surface of alluvial fan, and consequently, its products were easily reworked by fluvial currents. Some accretionary lapilli and armoured lapilli survived redeposition and can be encountered in mixed fluvial-volcaniclastic sediments. Armoured mud balls developed under normal sedimentary processes involving sliding of unconsolidated material under gravitation.
\end{abstract}

\section{Kratka vsebina}

Območju Grada v severovzhodni Sloveniji daje pečat zgornjepliocenska vulkanska aktivnost, s katero so nastali manjši izlivi lave in vulkanoklastiti, ki sestoje iz lapilov skorije. V poznem obdobju vulkanske aktivnosti so prevladovale hidrovulkanske eksplozije, ki so povzročile nastanek piroklastičnih valov, bogatih z akrecijskimi lapili. Ta alkalni bazaltni (basanitni) vulkanizem se je pojavil na površju aluvijalnega vršaja, zato so rečni tokovi vulkanite kmalu razgradili in jih pomešane $\mathrm{z}$ drugim sedimentnim materialom odložili kot fluvialno-vulkanoklastične sedimente. Tudi nekateri akrecijski lapili in oblepljeni lapili so preživeli presedimentacijo, zato jih najdemo tudi v mešanih fluvialno-vulkanoklastičnih sedimentih. Oblepljene muljaste krogle so nastale zaradi normalnih sedimentacijskih dejavnikov, kot je drsenje nekonsolidiranega materiala zaradi gravitacije.

\section{Introduction}

Accretionary lapilli are spherical aggregates of ash. They are not commonly encountered in Tertiary volcaniclastics of Slovenia. The most probable reason for that is in predominant submarine depositional environment, which is not very favourable for the formation of accretionary lapilli.
Most accretionary lapilli form in subaerial environments, and they are especially common in deposits of phreatomagmatic or hydrovolcanic eruptions, for example, surge deposits of tuff rings, silicic phreatomagmatic (phreatoplinian) eruptions and fall deposits from ash clouds that accompany pyroclastic flows and surges (M c P h i e et al., 1993). 
The formation of accretionary lapilli usually involves suspended ash and moisture. Suspended ash particles begin to aggregate around some nucleus, either a water droplet or solid particle (M c $\mathrm{P}$ h i e et al., 1993; C a s \& W r i g h t, 1987). Aggregating ash is held together by surface tension of condensed moisture, electrostatic forces, particle interlocking and growth of new minerals as the condensed moisture evaporites.

The sizes of accretionary lapilli vary from 3-4 $\mathrm{mm}$ to over $10 \mathrm{~cm}$. Some accretionary lapilli consist of a core of coarse-grained ash, surrounded by a rim of finer ash. Another type consists of aggregates of relatively coarse ash without a finer-grained rim. Armoured lapilli consist of crystal-, pumice- or lithic-fragment nuclei, coated by fine to coarse ash ( $\mathrm{M} \mathrm{c} \mathrm{P} \mathrm{h}$ i e et al., 1993). Armoured mud balls are large accretionary structures described by $\mathrm{D}$ i $\mathrm{m} \mathrm{roth}$ and $\mathrm{Y}$ a $\mathrm{m}$ a g i s h i (1987). These have a mudstone intraclast nuclei that is surrounded by concentric shells of ash, and are 6-10 $\mathrm{cm}$ in diameter.

Late Pliocene fluvial-volcaniclastic complex at Grad, northeastern Slovenia, comprises the remains of deposits, which consist of tuffs rich in accretionary lapilli; armoured lapilli are also encountered, but they are subordinate in occurrence. The deposits were settled by pyroclastic surges, related to hydrovolcanic explosions. Armoured mud balls overlie scoria flow deposits and they were produced by a massflow.

The aim of this contribution is to emphasise the importance of accretionary lapilli and pyroclastic surge deposits of the Grad complex as they prove the existence of hydrovolcanic stage of volcanic activity.

\section{Geological setting of the Grad fluvial- volcaniclastic complex}

The Grad fluvial-volcaniclastic complex occurred in Late Pliocene in the Mura basin, which forms a part of the widespread system of Pannonian basins. Alkali basaltic volcanic activity is closely related to that in the neighbouring Styrian basin in southeastern Austria (Fig. 1). The basins are sepa- rated by the South Burgenland horst where large lava flows of nephelinite, nepheline basalts and basanites erupted (Poulditis, 1981).

Effusive volcanic activity in the Styrian basin was also accompanied by intensive explosive volcanism which produced maars and tuff rings and tuff cones. The most important occurrences in the Styrian basin are at Beistein (Poschl, 1991), at Kapfenstein (W i n kle r, 1927) and Neuhaus.

In Late Pliocene, intensive subsidence of the Mura basin begun. A deep-seated fault developed along the South Burgenland horst forming the Radgona depression, which was the site of intensive fluvial sedimentation with the transport directions from norht-west to south-east. A system of alluvial fans developed and furtheron, they evolved into braided rivers.

Alkali basaltic volcanism at Grad occurred on the surface of alluvial fan. In the beginning, this volcanic activity produced smaller lava flows, and possibly, a small cinder cone, too. The late stage of volcanic activity was characterised by the dominant hydrovolcanic - phreatomagmatic and phreatic activity, which destroyed the former volcanic deposits, produced pyroclastic surge deposits and triggered large debris flows ( $\mathrm{K} \mathrm{r}$ a l j, 1995).

The surface of alluvial fan is very dynamic environment, and volcaniclastic deposits produced by effusive and explosive volcanic activity were immediately resedimented by fluvial currents. Today, redistributed and texturally mixed fluvial-volcaniclastic sediments vastly predominate in the Grad complex, and they practically bear the only information about the existence of the primary volcanic and volcaniclastic rocks in the area.

\section{Lithofacieses recognised in the Grad fluvial-volcaniclastic complex}

Lithofacieses, recognised in the Grad fluvial-volcaniclastic complex were subdivided into the following groups ( $\mathrm{Kr} \mathrm{a} \mathrm{l} \mathrm{j,} \mathrm{1995):}$

- pyroclastic flow deposits

- pyroclastic surge deposits

- debris flow deposits 


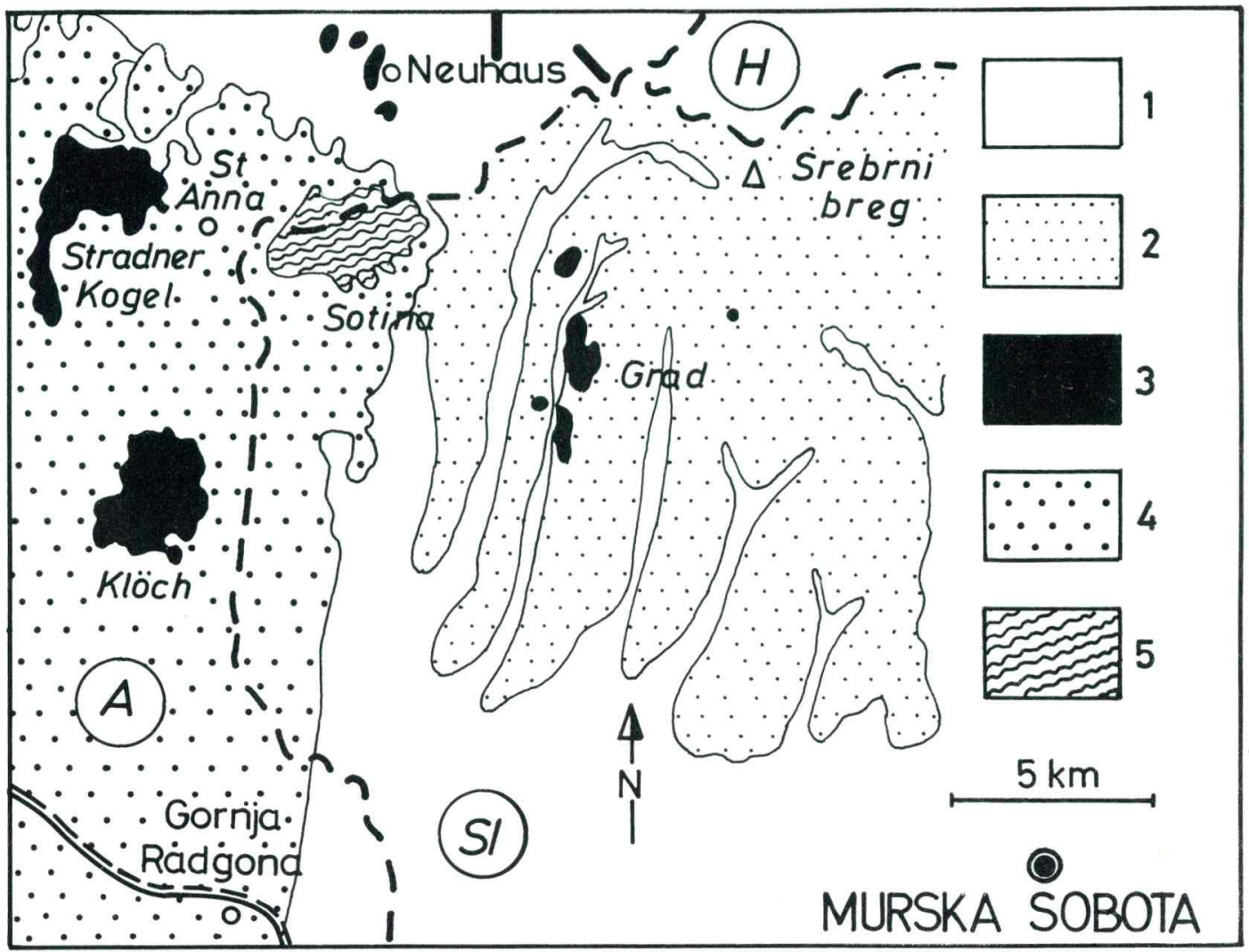

Fig. 1. Simplified geological map of the Grad area and a part of the neighbouring regions in Austrian Styria (modified from Win k le r, 1927; O ber ha us er, 1980).

Sl. 1. Poenostavljena geološka karta področja Grada in dela sosedne Avstrije, (prirejeno po W i n k l e r ju, 1927 in Oberhauserju, 1980).

1 - Quarternary, kvartar; 2 - Pliocene, pliocen; 3 - Upper Pliocene basaltic volcanics, zgornjepliocenske bazaltne predornine; 4 - Sarmatian, sarmatij; 5 - Pre-Tertiary basement, predterciarna podlaga.

- hyperconcentrated flow deposits, and - diluted debris flow deposits

Pyroclastic flow deposits and pyroclastic surge deposits are very rare in occurrence and they are encountered only as smallscale erosional remains among the predominating redistributed sediments. Pyroclastic flow deposits form up to 7 metres thick massive, lensoidal deposits, which mainly consist of scoria lapilli. Overlying massflow deposits are up to $0.7 \mathrm{~m}$ thick and contain armoured mud balls.

Pyroclastic surge deposits are characterised by low-angle cross stratification and horizontal stratification. The main constituents are lapilli of scoria and basaltic lithics; non-volcanic fluvial detritus form up to $35 \%$ of the bulk rock. The rock is strongly fines-depleted. Some strata are very rich in accretionary lapilli (Plate 1 - Fig. 1).

Debris flow deposits are the dominant lithofacies in the Grad complex. According to their grain-size analyses, they are gravelly sands or sandy gravels with subordinate amounts of silt $(7-25 \%)$, and up to $3 \%$ of clay. They form massive, up to 50 metres thick deposits with erosional base contacts. Debris flow deposits may contain some accretionary lapilli.

Hyperconcentrated flow deposits are horizontally- and cross-stratified conglomeratic sands and sands, very commonly inversely graded. They are overlain by, or interstratified with diluted debris flow deposits. 
Table 1. Mineral composition of accretionary lapilli from pyroclastic surge deposit (A), and armoured mud ball from mass-flow deposit which overlies pyroclastic flow deposit (B). Abundances are in wt. \% and estimated from X-ray diffraction patterns by Miha Mišič (Geological Survey of Slovenia, unpub data).

Tabela 1. Mineralna sestava akrecijskih lapilov iz vulkanoklastitov piroklastičnega vala (A) in oblepljena muljasta krogla iz vulkanoklastičnih sedimentov masnega toka, ki leže nad vulkanoklastiti piroklastičnega toka (B). Količine, podane v \%, je ocenil iz zapisa rentgenske difrakcije Miha Mišič iz Geološkega zavoda Slovenije (neobjavljeni podatki z dovoljenjem analitika)).

\begin{tabular}{|l|l|l|l|l|l|l|}
\hline $\begin{array}{l}\text { Mineral/ } \\
\text { Sample }\end{array}$ & Illite & Ca-mtm. & Kaolinite & Quartz & Augite & Hematite \\
A & 32 & 25 & 12 & 18 & 7 & 5 \\
B & 35 & 25 & 15 & 15 & 5 & 5 \\
\hline
\end{tabular}

Ca-mtm. - calcic montmorillonite, kalcijski montmorillonit

\section{Accretionary lapilli}

Accretionary lapilli vary in size from less than $2 \mathrm{~mm}$ to over $15 \mathrm{~mm}$, but the most commonly, their sizes vary from 5 and 10 $\mathrm{mm}$. The texture of accretionary lapilli is usually concentric: the core consists of coarser tuff (Plate 1 - Fig. 2), and the outer shells of progressively finer tuff. Petrographic analysis indicate that some of them include appreciable amounts of terrigenous material (Plate 1 - Fig. 2). Mineral composition of accretionary lapilli and armoured mud balls is presented in Table 1 .

Armoured lapilli also occur in pyroclastic surge deposits, although they are less abundant as accretionary lapilli. They consist of the core of basaltic lithic fragments, coated by fine-grained material. Armoured lapilli are encountered in resedimented fluvial-volcaniclastic deposits, too. Their outer, fine-grained shells are strongly abraded. Very commonly, they only consist of thin veneer of volcanic ash, which is better preserved in the concave parts of the lithic fragments (Plate 1 - Fig. 3). Resedimented armoured lapilli are hardly distinguished from resedimented lithic fragments, coated by fine grained matrix that was not com- pletely washed out during reworking processes.

Armoured mud balls (Plate 1 - Fig. 4) are eliptical aggregates, composed of a muddy core and the outher shells of the same composition. They range in size from $2 \mathrm{~cm}$ to 10 $\mathrm{cm}$. Their formation is probably related to normal sedimentary processes of sliding of unconsolidated mud which was rolled up into rounded aggregates.

\section{Conclusions}

Accretionary lapilli and armoured lapilli are encountered in pyroclastic surge deposits of the Grad complex, and they are related to hydrovolcanic activity. Alkali basaltic (basanitic) magma probably met an intergranular aquifer during its rise to the surface, as a thick pile of coarse-grained fluvial sediments accumulated in the Radgona depression. Volcanic explosions, rich in water vapor, are very favorable for aggregating of volcanic ash and formation of accretionary lapilli. Accretionary lapilli, the coating of armoured lapilli, and armoured mud balls also include fine-grained clastic sedimentary material. 


\section{Literature}

C a s, R.A.F .\& W r i g h t, J.V. 1987: Volcanic successions. Allen \& Unwin,528pp., London.

D i m r o th, E., Y a m a g is hi, H. 1987: Criteria for the recognition of ancient subaqueous rocks. -Geol. Surv. Hokkaido Rep. 58, 55-88, Sapporo.

K r a 1 j, P. 1995: Gornjepliocenski fluvialni i klastični sedimenti područja Grada u sjeveroistočnoj Sloveniji. - Ph.D. Thesis, University of Zagreb, 128p., Zagreb.

M c P h i e, J., D o y 1 e, M. \& A 11 e n, R. 1993: Volcanic textures. - Centre for Ore Deposits and Exploration Studies, University of Tasmania, 198pp., Hobart.
O b e r h a u s e r, R. (ed.) 1980: Der geologische Aufbau Österreichs.-Springer, 700 pp., Wien.

P o s c h 1, I. 1991: A model for depositional evolution of volcaniclastic successions of Pliocene maar volcano in the Styrian basin (Austria). - Jb. Geol. B.-A. 134/4, 809-843, Wien.

P o uld it is, Ch. 1981: Petrologie und Geochemie basaltischer Gesteine der steierischen Vulkanbogens in der Steiermark und im Burgenland. - Diss. Univ. Wien, 164 pp., Wien.

W i n k l e r, A. 1927: Erlauterungen zur geologischen Spezialkarte der Republik Österreich, Blatt Gleichenberg - Geologische Bundesanstalt, 1-164, Wien. 


\section{Plate 1 - Tabla 1}

1 Outcropping of pyroclastic surge deposits, rich in accretionary lapilli at Popovšček Izdanek vulkanoklastitov na Popovščku, ki so nastali s piroklastičnim valom in vsebujejo veliko akrecijskih lapilov

2 Accretionary lapilli from a debris-flow deposit

Akrecijski lapil iz debritnih sedimentov

3 Strongly abbraded armoured lapilli from fluvial deposits

Močno abradiran oblepljen lapil iz fluvialnih sedimentov

4 Armoured mud balls from mass flow deposits that overlie pyroclastic flow deposits

Oblepljena muljasta krogla iz sedimentov, ki so nastali z drsenjem nekonsolidiranega materiala. Pod njimi so vulkanoklastiti piroklastičnega toka 

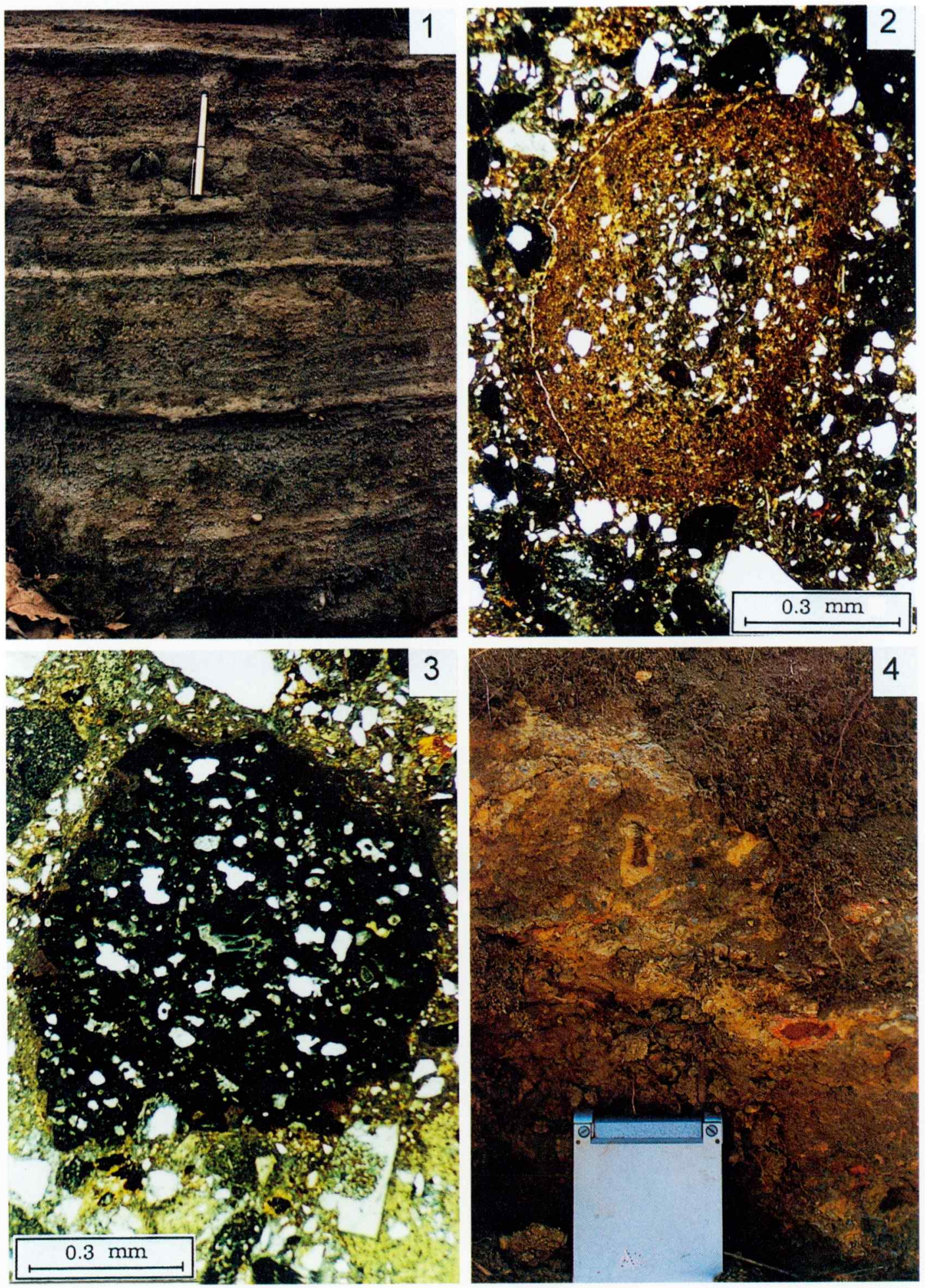